Halaman 1-11

\title{
Studi Komparasi Penerapan Model Pembelajaran Problem Based Learning dan Inkuiri Terbimbing terhadap Keterampilan Proses Sains Siswa Kelas X SMA Negeri 3 Boyolali Tahun Pelajaran 2013/2014
}

\author{
The Comparison Study of Using Problem Based Learning and Guided Inquiry \\ Toward Student's Science Process Skill of X Grade Students \\ At SMA Negeri 3 Boyolali in 2013/2014 Academic Year \\ Muhamad Yutam Soleh ${ }^{a}$, Slamet Santosa ${ }^{b}$, Meti Indrowati ${ }^{c}$ \\ ${ }^{a}$ Pendidikan Biologi FKIP UNS, Email: yutamega@gmail.com \\ ${ }^{\mathrm{b}}$ Pendidikan Biologi FKIP UNS, Email: slametsantosa_bio@yahoo.com \\ ${ }^{\mathrm{c}}$ Pendidikan Biologi FKIP UNS, Email: metindrowati@yahoo.co.id
}

Diterima 7 Juli 2014, disetujui 10 Agustus 2014

\begin{abstract}
The purpose of this research are to determine the differences result in Sciences Process Skills (SPS) with using Problem Based Learning and guided inquiry of $\mathrm{X}$ grade students at SMA Negeri 3 Boyolali in 2013/2014 academic year. This research was quasi experiment research which used Posttest Only With Nonequivalent Control Group design by using the experimental 1 class (application of Problem Based Learning) and experimental 2 class (application of guided inquiry). The population studies are all $\mathrm{X}$ class students of SMA Negeri 3 Boyolali in academic year 2013/2014. Sampling technique is using cluster sampling, the classroom that is chosen are X.1 as the experiment 1 class and X.3 as the experimental 2 class. The techique of collecting data is using essay test for measuring of SPS classifying, using tool and material, hypothesizing, formulate ways of working, predicting and communicating. Non-test technique is using methods of documentation and observation methods for measuring of SPS using the tool and material, observing and experimenting. The data were analyzed by t-test assisted SPSS 16 . The result of this research concluded that there are differences results between Problem Based Learning and guided inquiry toward student's sciences process skills of $X$ grade students at SMA Negeri 3 Boyolali.
\end{abstract}

Key Words: Problem Based Learning, Guided Inquiry, Science Process Skills

\section{Pendahuluan}

Pembelajaran merupakan upaya

yang dilakukan untuk memahami pengetahuan yang dipelajari. Pembelajaran perlu menumbuhkan interaksi antara peserta didik dengan pendidik dan sumber belajar pada suatu lingkungan belajar. Belajar biologi pada tingkat SMA semestinya dibelajarkan dengan menumbuhkan interaksi peserta didik dan guru karena pembelajaran biologi menuntut pembelajran aktif yang akan melatihkan kemampuan intelegensi, keterampilan proses dan sikap ilmiah.

$$
\text { Pembelajaran biologi sebagai }
$$
sains harus dibelajarkan secara aktif yang mampu menumbuhkan proses atau kegiatan siswa dalam mempelajari gejala alam menggunakan pikiran dan sikap ilmiah. Pembelajaran biologi yang aktif mengembangkan kemampuan proses dan kemampuan belajar mandiri siswa dalam melihat, mengeksplorasi, memecahkan 
masalah, dan mencari pemahaman baru. Pembelajaran biologi yang aktif akan membiasakan siswa untuk mengembangkan keterampilan proses sains (KPS) pada saat pembelajaran. Keterampilan proses sains adalah keterampilan dalam berproses yang melibatkan keterampilan-keterampilan kog-nitif atau intelektual, manual dan sosial (Rustaman, 2005).

Keterampilan proses sains menurut Akinbobola \& Afolabi (2010) diartikan sebagai kemampuan mental dan fisik dan kompetensi yang berfungsi sebagai alat yang diperlukan untuk memperlajari pengetahuan dan teknologi serta pemecahan masalah. Özgelen (2012) menyatakan bahwa keterampilan proses sains (KPS) adalah keterampilan berpikir yang digunakan oleh ilmuwan untuk membangun pengetahuan dalam rangka memecahkan masalah dan merumuskan hasil.

Subali (2010) mengelompokkan keterampilan proses sains (KPS) menjadi dua yakni KPS dasar dan KPS terintegrasi. Keterampilan proses sains dasar menjadi dua yakni keterampilan dasar (basic skill) dan keterampilan mengolah/ memproses (process skill). Pengelompokan keterampilan proses sains dapat dilihat pada Tabel 1.
Tabel 1. Pengelompokan KPS

\begin{tabular}{ll}
\hline \multicolumn{1}{c}{ KPS Dasar } & \multicolumn{1}{c}{ KPS Terintegrasi } \\
\hline Mengamati & Merumuskan \\
Mengelompokan & hipotesis \\
Mengukur & Mengontrol variabel \\
Mengkomunikasikan & Menafsirkan data \\
Memprediksi & Merancang \\
Menggunakan & percobaan \\
hubungan ruang & Bereksperimen \\
Menggunakan angka & Menyusun definisi \\
Menyimpulkan & operasional \\
\hline (Sumber: Subali, 2010) & \\
\multicolumn{1}{c}{ Pengembangan } & KPS dalam ke-
\end{tabular}
giatan pembelajaran membutuhkan model pembelajaran yang tepat dan sesuai dengan siswa. Keterampilan proses perlu dikembangkan melalui pengalaman langsung sebagai pengalaman belajar, dan disadari ketika kegiatanya sedang berlangsung (Rustaman, 2005). Penggunaan model pembelajaran yang tepat dan sesuai dapat membangkitkan keterlibatan aktif siswa dalam kegiatan pembelajaran. Model pembelajaran yang dapat mengembangkan KPS dalam fase pembelajarannya adalah model pembelajaran yang memunculkan keterlibatan aktif siswa dalam pembelajaran seperti model pembelajaran Problem Based Learning dan model inkuiri terbimbing.

Model pembelajaran Problem Based Learning pada esensinya adalah model pembelajaran yang berlandaskan konstruktivisme dan mengakomodasi keterlibatan siswa dalam belajar serta terlibat dalam pemecahan masalah yang kontekstual. Etherington (2011) menyata- 
kan bahwa pembelajaran dengan menggunakan model Problem Based Learning dapat memberdayakan peserta didik agar bertanggung jawab untuk melaksanakan pembelajaran, mendefinisikan dan menganalisis masalah dan menemukan sebuah solusi untuk masalah yang dihadapi melalui kegiatan penyelidikan. Tan (2003) menyatakan model Problem Based Learning memiliki beberapa karakteristik yakni keberadaan masalah nyata sebagai titik awal pembelajaran, masalah yang ada merupakan masalah berbagai disiplin ilmu, pembelajaran aktif dilakukan oleh siswa sebagai subjek belajar, memerlukan penyelidikan untuk memecahkan masalah yang dihadapi serta mencari solusinya.

Warsono \& Hariyanto (2012) menyatakan langkah-langkah pelaksanaan model pembelajaran Problem Based Learning tediri atas lima tahap kegiatan meliputi kegiatan orientasi masalah kepada siswa, mengorganisasikan siswa untuk belajar, mendukung kelompok investigasi, mengembangkan dan mempresentasikan karya, menganalisis dan mengevaluasi proses penyelesaian masalah. Kegiatan siswa dalam sintaks model Problem Based Learning dapat dilihat pada Tabel 2.
Tabel 2. Kegiatan siswa dalam sintaks model pembelajaran Problem Based Learning

\begin{tabular}{llr}
\hline \multicolumn{1}{c}{ Sintaks } & \multicolumn{2}{c}{ Kegiatan Siswa } \\
\hline $\begin{array}{l}\text { Orientasi masalah } \\
\text { kepada siswa }\end{array}$ & $\begin{array}{l}\text { Memilih masalah yang } \\
\text { ada di lingkungan } \\
\text { sekitarnya } \\
\text { Mengorgani- }\end{array}$ & $\begin{array}{l}\text { Mementukan tema, } \\
\text { jadwal, tugas, dll } \\
\text { sasikan siswa } \\
\text { untuk belajar }\end{array}$ \\
$\begin{array}{l}\text { Mendukung } \\
\text { kelompok }\end{array}$ & $\begin{array}{l}\text { Mencari informasi, } \\
\text { bereksperimen dan } \\
\text { investigasi }\end{array}$ & $\begin{array}{l}\text { mencari penjelasan untuk } \\
\text { memecahkan masalah }\end{array}$ \\
Mengembangkan & $\begin{array}{l}\text { Membuat karya sesuai } \\
\text { tugas yang diberikan dan } \\
\text { dan }\end{array}$ \\
memrpresntasikan & $\begin{array}{l}\text { mempresentasikannya } \\
\text { hasilnya } \\
\text { hasil karya } \\
\text { Menganalisis dan } \\
\text { mengevaluasi }\end{array}$ & $\begin{array}{l}\text { Melakukan } \\
\text { pembelajaran refleksi }\end{array}$ \\
\hline
\end{tabular}

Akınoğlu \& Tandoğan (2007) menyatakan beberapa manfaat Model pembelajaran Problem Based Learning antara lain dapat mengembangkan tingkat sosialisasi dan keterampilan komunikasi siswa yang memungkinkan mereka untuk belajar dan bekerja dalam tim. Model pembelajaran Problem Based Learning dapat mengembangkan berpikir tingkat tinggi/ berpikir kritis siswa dan keterampilan berpikir ilmiah. Melalui Model pembelajaran Problem Based Learning siswa juga memperoleh keterampilan manajemen waktu, fokus, pengumpulan data, pembuatan laporan dan evaluasi.

Model pembelajaran inkuiri terbimbing merupakan salah satu bagian dari model inkuiri. Model inkuiri dibagi menjadi 4 level yakni inkuiri konfirmasi, inkuiri terstruktur, inkuiri terbimbing dan 
inkuiri bebas (Banchi \& Bell, 2008). Model pembelajaran inkuiri terbimbing merupakan model yang dianggap cocok untuk dibelajarkan pada pendidikan menengah dikarenakan model ini tidak terlalu memerlukan banyak waktu dalam menyelesaikan tahap pembelajarannya dan terdapat bimbingan guru untuk dapat mengarahkan peserta didik dalam belajar.

Pembelajaran inkuiri terbimbing siswa akan dipandu melalui proses penyelidikan ilmiah dalam pembelajaran. Dalam inkuiri terbimbing, guru mengarahkan untuk mengerti sesuatu dari apa yang mereka tidak mengerti. Aktivitas pembelajaran pada inkuiri terbimbing berpusat pada siswa di mana guru menggunakan berbagai bahan ajar untuk membantu siswa menemukan solusi yang mungkin diuji untuk penyelidikan ilmiah yang telah mereka didefinisikan.

$$
\text { Majid (2013) menyatakan }
$$

langkah-langkah pelaksanaan model pembelajaran inkuiri terbimbing tediri atas enam tahap kegiatan meliputi menyajikan masalah awal, merumuskan hipotesis, merancang percobaan, melaksanakan percobaan, menganalisis data percobaan, menarik kesimpulan. Kegiatan siswa dalam sintaks model pembelajaran inkuiri terbimbing dapat dilihat pada Tabel 3.
Tabel 3. Kegiatan siswa dalam sintaks model pembelajaran inkuiri terbimbing

\begin{tabular}{|c|c|}
\hline $\begin{array}{c}\text { Tahap } \\
\text { Pembelajaran }\end{array}$ & Kegiatan Siswa \\
\hline $\begin{array}{l}\text { Menyajikan } \\
\text { masalah awal }\end{array}$ & $\begin{array}{l}\text { Mengidentifikasi dan } \\
\text { merumuskan masalah }\end{array}$ \\
\hline $\begin{array}{l}\text { Merumuskan } \\
\text { hipotesis }\end{array}$ & Merumuskan hipotesis \\
\hline $\begin{array}{l}\text { Merancang } \\
\text { percobaan }\end{array}$ & Merancang percobaan \\
\hline $\begin{array}{l}\text { Melaksanakan } \\
\text { percobaan }\end{array}$ & $\begin{array}{l}\text { Melaksanakan percobaan } \\
\text { untuk mengumpulkan da- } \\
\text { ta/informasi }\end{array}$ \\
\hline $\begin{array}{l}\text { Menganalisis data } \\
\text { percobaan }\end{array}$ & $\begin{array}{l}\text { Menganalisis data hasil } \\
\text { percobaan }\end{array}$ \\
\hline $\begin{array}{l}\text { Menarik } \\
\text { kesimpulan }\end{array}$ & Menarik kesimpulan \\
\hline
\end{tabular}

Manfaat model pembelajaran inkuiri menurut Ketpichainarong, Panijpan \& Ruenwongsa (2008) adalah pengajaran dengan metode pembelajaran inquiri akan mempengaruhi kinerja siswa, misalnya dalam memecahkan masalah, merefleksikan pekerjaan mereka, menarik kesimpulan, dan memprediksi. Kinerja siswa yang demikian merupakan cerminan dari keterampilan proses sains yang terlatihkan dengan model pembelajaran inkuiri terbimbing.

\section{Model pembelajaran Problem}

Based Learning dan model inkuiri terbimbing dipandang dapat memunculkan keterlibatan siswa dalam pembelajaran sehingga pembelajaran akan menjadi pembelajaran yang aktif dan melatihkan keterampilan proses sains yang merupakan bagian dari pembelajaran sains. Model pembelajaran Problem Based Learning dan model 
inkuiri terbimbing memiliki langkah pembelajaran dan karakteristik yang berbeda, sehingga kedua pembelajaran tersebut dapat memberikan hasil yang berbeda terhadap ketrampilan proses sains siswa dalam kegiatan pembelajaran.

Penelitian ini bertujuan untuk mengetahui ada tidaknya perbedaan keterampilan proses sains dengan penerapan model pembelajaran Problem Based Learning dan inkuiri terbimbing pada siswa kelas X SMA Negeri 3 Boyolali tahun pelajaran 2013/2014.

\section{Metode Penelitian}

Penelitian ini termasuk penelitian eksperimen semu dengan pendekatan kuantitatif. Desain penelitian adalah posttest only with nonequivalent group design dengan menggunakan 2 kelas eksperimen. Proses pembelajaran pada kelas eksperimen 1 menggunakan model pembelajaran Problem Based Learning dan proses pembelajaran pada kelas eksperimen 2 menggunakan model pembelajaran inkuiri terbimbing.

Populasi dalam penelitian ini adalah siswa kelas X SMA Negeri 3 Boyolali tahun pelajaran 2013/2014 yang berjumlah 8 kelas. Pengambilan sampel dilakukan dengan teknik cluster sampling. Sampel yang terpilih adalah kelas X.1 sebagai kelas eksperimen 1 dan kelas X.3 sebagai kelas eksperimen 2.
Variabel terikat pada penelitian ini adalah Keterampilan Proses Sains (KPS) dan variabel bebas adalah model pembelajaran Problem Based Learning dan model pembelajaran inkuiri terbimbing. Analisis instrumen penelitian menggunakan uji validitas dan reliabilitas.

Teknik pengumpulan data yang digunakan dalam penelitian ini menggunakan teknik dokumentasi, tes dan observasi. Pengumpulan data dengan teknik dokumentasi dilakukan dengan mengumpulkan nilai ulangan tengah semester siswa yang kemudian digunakan untuk uji keseimbangan sampel sebelum penentuan sampel dilakukan. Data keterampilan proses sains diperoleh dari teknik tes yang berupa tes KPS yang berbentuk soal uraian. Teknik observasi menggunakan lembar observasi digunakan untuk mendapatkan data KPS dan juga digunakan untuk mengetahui keterlaksanaan sintaks model pembelajaran Problem Based Learning dan inkuiri terbimbing. Teknik analisa data menggunakan uji-t.

\section{Hasil dan Pembahasan}

Data hasil penelitian adalah nilai keterampilan proses sains (KPS) yang diperoleh dari tes KPS dan observasi KPS. Data dianalisis menggunakan uji-t untuk mengetahui perbedaan hasil dari 
penerapan model pembelajaran Problem Based Learning dan inkuiri terbimbing terhadap KPS.

\section{Uji hipotesis}

Hasil analisis ada tidaknya perbedaan keterampilan proses sains hasil dari penerapan model pembelajaran Problem Based Learning dan Inkuiri Terbimbing menggunakan uji-t dapat dilihat pada Tabel 4.

Tabel 4. Hasil Uji-t KPS

\begin{tabular}{rrcc}
\hline Sumber & Sig. & Hasil & Keputusan \\
\hline Nilai KPS & 0,013 & $0,013<0,05$ & $\mathrm{H}_{0}$ ditolak \\
\hline
\end{tabular}

Hasil uji menggunakan uji-t menunjukkan bahwa nila sig $(0,013)<$ 0,05 maka $\mathrm{H}_{\mathrm{O}}$ ditolak, sehingga dapat diambil keputusan bahwa $\mathrm{H}_{1}$ diterima, artinya ada perbedaan keterampilan proses sains siswa pada kelas eksperimen 1 dengan model pembelajaran Problem Based Learning dan kelas eksperimen 2 dengan model pembelajaran inkuiri terbimbing.

Pelaksanaan kegiatan pembelajaran dengan menggunakan model Problem Based Learning dan inkuiri terbimbing menghasilkan data nilai keterampilan proses sains (KPS) yang diukur menggunakan lembar observasi dan tes KPS. Data hasil penelitian menunjukan bahwa nilai rata-rata kelompok eksperimen 1 memiliki nilai 71,00 dan nilai rata-rata kelompok eksperimen 2 adalah 65,97 yang berarti rata-rata nilai KPS siswa kelompok eksperimen 1 lebih tinggi daripada kelompok eksperimen 2. Hasil uji hipotesis yang menggunakan uji-t dibantu program SPSS 16 menunjukkan bahwa bahwa nilai Sig $(0,013)<0,05$ sehingga $\mathrm{H}_{0}$ ditolak yang berarti terdapat perbedaan keterampilan proses sains siswa dengan penerapan model pembelajaran Problem Based Learning dan inkuiri terbimbing pada siswa kelas $\mathrm{X}$ SMA Negeri 3 Boyolali tahun pelajaran 2013/2014.

Perbedaan keterampilan proses sains yang muncul diakibatkan adanya perbedaan langkah-langkah pembelajaran dari kedua model pembelajaran yang diterapkan sehingga pengalaman langsung dalam belajar yang diperoleh siswa dalam pembelajaran berbeda. Rustaman (2005) menyatakan bahwa keterampilan proses perlu dikembangkan melalui pengalaman langsung sebagai pengalaman belajar dan disadari ketika kegiatannya sedang berlangsung.

Rustaman, (2005) menyatakan Keterampilan Proses Sains (KPS) melibatkan beberapa keterampilan antara lain keterampilan kognitif atau intelektual, manual dan sosial. Keterampilan kognitif terlibat ketika siswa menggunakan pikirannya. Keterampilan manual jelas terlibat saat siswa melakukan penggunaan alat dan 
bahan, pengukuran dan perakitan alat. Keterampilan sosial diwujudkan ketika siswa berinteraksi dengan siswa lainnya.

Model pembelajaran Problem Based Learning terdiri dari suatu proses penyajian situasi masalah autentik yang dapat memberikan kemudahan kepada siswa dalam melakukan proses pembelajaran. Model Problem Based Learning dikembangkan untuk mengembangkan keterampilan berpikir, mengembangkan pengetahuan dan keterampilan proses. Keterampilan proses dilatihkan kepada siswa pada proses pembelajaran yang dilakukan dalam sintaks model pembelajaran Problem Based Learning. Kegiatan proses pembelajaran ditandai dengan siswa melakukan tindakan kerja yang mereka lakukan untuk memecahkan masalah yang disajikan. Saat proses pembelajaran dilakukan oleh siswa, maka banyak keterampilan proses sains yang dilatihkan kepada siswa (Rusnayati \& Prima, 2011).

Yuniastuti (2013) menyatakan pada model inkuiri terbimbing, siswa dihadapkan pada tugas yang relevan untuk diselesaikan baik melalui diskusi kelompok maupun individual agar mampu menyelesaikan masalah dan menarik kesimpulan secara mandiri, akan tetapi siswa tetap memperoleh pedoman/ bimbingan berupa pertanyaan atau diskusi serta pemantauan dari guru.
Kegiatan inkuiri sangat penting karena dapat mengoptimalkan keterlibatan pengalaman langsung siswa dalam proses pembelajaran dan melatihkan keterampilan proses sains (Paidi, 2006). Bilgin (2009) menyatakan dalam metode inkuiri terbimbing, guru memiliki peranan penting dalam mengajukan pertanyaan pada peserta didik untuk mengembangkan jawaban dari pertanyaan-pertanyaan yang diajukan. Kegiatan inkuiri terbimbing membantu siswa untuk mengembangkan tanggung jawab individual, kemampuan kognitif, kegiatan pemecahan masalah dan pemahaman keterampilan proses.

Keterampilan proses sains (KPS) yang dilatihkan antara lain KPS mengamati, mengelompokkan, merumuskan hipotesis, menggunakan alat dan bahan, merencanakan percobaan, melaksanakan percobaan, mengkomunikasikan, dan memprediksi. Nilai rata-rata tiap aspek KPS pada kelas eksperimen 1 dan kelas eksperimen 2 dapat dilihat pada Tabel 5. 
Tabel 5. Nilai Rata-Rata Tiap Aspek KPS Pada Kelas Eksperimen 1 Dan Eksperimen 2

\begin{tabular}{lcc}
\hline Aspek KPS & $\begin{array}{c}\text { Kelas } \\
\text { Eksperimen } \\
\mathbf{1}\end{array}$ & $\begin{array}{c}\text { Kelas } \\
\text { Eksperimen } \\
\mathbf{2}\end{array}$ \\
\hline $\begin{array}{l}\text { Mengamati } \\
\text { Mengguna- }\end{array}$ & 66.4 & 75.4 \\
kan Alat & 78.1 & 78.1 \\
Bahan & & \\
$\begin{array}{l}\text { Melakukan } \\
\text { Percobaan }\end{array}$ & 89.1 & 91.4 \\
$\begin{array}{l}\text { Merencana- } \\
\text { kan }\end{array}$ & 79.3 & 57.8 \\
$\begin{array}{l}\text { Percobaan } \\
\text { Merumuskan }\end{array}$ & 66.4 & \\
$\begin{array}{l}\text { Hipotesis } \\
\text { Memprediksi }\end{array}$ & 53.1 & 32.8 \\
$\begin{array}{l}\text { Mengkomun- } \\
\text { ikasikan }\end{array}$ & 58.2 & 52.0 \\
$\begin{array}{l}\text { Mengelomp- } \\
\text { okkan }\end{array}$ & 77.3 & 56.6 \\
\hline
\end{tabular}

Tabel 3 menunjukan nilai ratarata tiap aspek KPS yang diukur pada masing masing kelompok eksperimen. KPS yang memiliki nilai yang paling tinggi dari kedua kelompok eksperimen adalah KPS melakukan percobaan, sedangkan aspek KPS yang paling rendah pada kelompok eksperimen 1 adalah aspek memprediksi dan pada kelompok eksperimen 2 adalah KPS merumuskan hipotesis. Keterampilan melakukan percobaan mendapatkan nilai yang paling tinggi pada kedua kelas eksperimen dikarenakan model pembelajaran yang diterampkanpada masing masing kelas eksperimen adalah model pembelajaran yang memunculkan kegiatan penyelidikan dalam pembelajarannya. Kerangka utama dari model pembelajaran Problem Based
Learning dan inkuiri terbimbing ialah kegiatan penyelidikan (Ünver \& Arabacioğlu).

Urutan nilai rata-rata KPS yang paling tinggi menuju nilai yang paling rendah pada kelompok eksperimen 1 adalah KPS melakukan percobaan, merencanakan percobaan, menggunakan alat bahan, mengelompokkan, mengamati, merumuskan hipotesis, mengkomunikasikan dan KPS memprediksi. Urutan nilai rata-rata KPS yang paling tinggi menuju nilai yang paling rendah pada kelompok eksperimen 2 adalah KPS melakukan percobaan, mengelompokkan, menggunakan alat bahan, mengamati, merencanakan percobaan, mengkomunikasikan, memprediksi dan KPS merumuskan hipotesis.

Kelas eksperimen 1 yang menggunakan model pembelajaran Problem Based Learning memiliki nilai ratarata keterampilan proses sains siswa senilai 71. Nilai rata-rata ini sudah mencapai batas KKM biologi yang ditetapkan yakni 70. Nilai rata-rata yang telah mencapai KKM ini menunjukkan bahwa 8 aspek keterampilan proses sains yang dilatihkan sudah cukup baik. Kelas eksperimen 2 yang menggunakan model pembelajaran inkuiri terbimbing memiliki nilai rata-rata keterampilan proses sains siswa hanya mendaptakan nilai 66. Nilai rata-rata ini belum 
mencapai batas KKM biologi yang ditetapkan yakni 70. Aspek KPS yang dilatihkan menggunakan model pembelajaran inkuiri terbimbing tidak semua terlatihkan dengan baik.. Hasil yang diperoleh ini tidak sesuai dengan beberapa penelitian yang menggunakan model pembelajaran inkuiri terbimbing dalam melatihkan keterampilan proses sains. Penelitian yang dilakukan oleh Rustaman (2005) menyatakan bahwa pembelajaran biologi melalui kegiatan inkuiri dapat meningkatkan keterampilan proses sains.

Ketidaksesuian hasil penelitian pada kelas eksperimen 2 dengan teori dan penelitian lain dapat dikarenakan oleh banyak faktor yang muncul dalam proses pembelajaran. Andriani, Husaini, \& Nurliyah (2011) menyebutkan bahwa adapun beberapa kekurangan dari model pembelajaran inkuiri terbimbing diantaranya adalah suasana kelas menjadi ramai yang memungkinkan mengganggu proses pembelajaran dan konsentrasi siswa dalam proses pembelajaran dan juga terdapat kelemahan fungsi guru dalam mengelola suasana kelas. Sifat siswa yang terkadang sudah merasa puas dan bisa terkadang tidak membuat siswa kurang tertarik untuk mengindahkan bimbingan guru.

Berdasarkan dari uji statistik dan pembahasan di atas dapat dilihat bahwa terdapat perbedaan hasil dari penerapan model pembelajaran Problem Based Learning dan inkuiri terbimbing terhadap keterampilan proses sains siswa. Perbedaan keterampilan proses sains dapat dilihat dari nilai rata-rata keterampilan proses sains siswa pada kelompok eksperimen 1 yang memiliki nilai rata-rata seniali 71 yang lebih tinggi daripada kelompok eksperimen 2 yakni senilai 65,97. Perbedaan ini dapat digunakan untuk menyimpulkan bahwa terdapat perbedaan hasil dari penerapan model pembelajaran Problem Based Learning dan model pembelajaran inkuiri terbimbing terhadap keterampilan proses sains siswa kelas X SMA Negeri 3 Boyolali tahun pelajaran 2013/2014.

\section{Kesimpulan}

Berdasarkan hasil penelitian dengan tujuan mengetahui ada tidaknya perbedaan keterampilan proses sains dengan penerapan model pembelajaran Problem Based Learning dan Inkuiri Terbimbing disimpulkan bahwa terdapat perbedaan keterampilan proses sains dengan penerapan model pembelajaran Problem Based Learning dan Inkuiri Terbimbing terhadap pada siswa kelas $\mathrm{X}$ SMA Negeri 3 boyolali tahun pelajaran 2013/2014. 


\section{Daftar Pustaka}

Akinbobola, A.O., \& Afolabi, F. (2010). Analysis Of Science Process Skills In West African Senior Secondary School Certificate Physics Practical Examinations In Nigeria. Bulgarian Journal Of Science And Education Policy (BJSEP). 4(1),32-47

Akınoğlu, O., \& Tandoğan, R. Ö. (2007). The Effects of Problem-Based Active Learning in Science Education on Students' Academic Achievement, Attitude and Concept Learning. Eurasia Journal of Mathematics, Science \& Technology Education. 3(1), 71-81

Andriani, N., Husaini, I., \& Nurliyah, L. (2011). Efektifitas Penerapan Pembelajaran Inkuiri Terbimbing (Guided Inquiry) pada Mata Pelajaran Fisika Pokok Bahasan Cahaya di Kelas VIII SMP Negeri 2 Muara Padang. Prosiding Simposium Nasional Inovasi Pembelajaran dan Sains 2011 (SNPS 2011), pp.1-6

Balanay, C.A.S. 2013. Assessment on Students' Science Process Skills: A Student- Centred Approach. International Journal of Biology Education 3. (1), 24-44

Banchi, H., Bell, R. (2008). The Many Levels of Inquiry. Science and Children

Bilgin, I. (2009). The effects of guided inquiry instruction incorporating a cooperative learning approach on university students' achievement of acid and bases concepts and attitude toward guided inquiry instruction . Scientific Research and Essay. 4 (10), 1038-1046

Etherington, M.B. (2011). Investigative Primary Science: A Problem-based Learning Approach. Australian Journal of Teacher Education. 36(9),36-57

Ketpichainarong, W., Panijpan, B., Ruenwongsa, P. (2008). Enhanced Learning Of Biotechnology Students By An Inquiry-Based Cellulase Laboratory. International Journal of En- vironmental \& Science Education. 3(3), 169-187

Majid, A. (2013). Strategi Pembelajaran. Bandung: PT Remaja Rosdakarya

Özgelen, S. (2012). Students' Science Process Skills within a Cognitive Domain Framework. Eurasia Journal of Mathematics, Science \& Technology Education. 8(4),283-292

Paidi. (2006). Peningkatan Scientific Skill Siswa Melalui Implementasi Metode Guided Inquiry Pada Pembelajaran Biologi Di SMAN 1 Sleman. Skripsi tidak dipublikasikan. Universitas Negeri Yogyakarta

Rusnayati,H. \& Prima, E.C. (2011). Penerapan Model Pembelajaran Problem Based Learning Dengan Pendekatan Inkuiri Untuk Meningkatkan Keterampilan Proses Sains Dan Penguasaan Konsep Elastisitas Pada Siswa Sma. Prosiding Seminar Nasional Penelitian, Pendidikan Dan Penerapan MIPA, Fakultas MIPA, Universitas Negeri Yogyakarta

Rustaman, N. (2005). Strategi Belajar Mengajar Biologi. Malang: UM Press

Rustaman, N. Y. (2005). Perkembangan Penelitian Pembelajaran Berbasis Inkuiri dalam Pendidikan Sains. Makalah dipresentasikan dalam Seminar Nasional II Himpunan Ikatan Sarjana dan Pemerhati Pendidikan IPA Idonesia Bekerjasama dengan FPMIPA. Universitas Pendidikan Indonesia, Bandung, 22-23 Juli

Subali, B. (2010). Pengukuran Keterampilan Proses Sains Pola Divergen Mata Pelajaran Biologi SMA di Provinsi DIY dan Jawa Tengah. Proceeding Seminar Nasional Biologi "Biologi dan Pengembangan Profesi Pendidik Biologi”. (pp.82-98). Yogyakarta: UNY

Tan, O. S. (2003). Problem-based Learning Innovation: Using problems to power learning in the 21st century. Cengage Learning 
Ünver, A.O \& Arabacioğlu, S. (2011). Overviews On Inquiry Based And Problem Based Learning Methods. Western Anatolia Journal of Educational Sciences (WAJES):303-310

Warsono \& Hariyanto. (2012). Pembelajaran Aktif. Bandung: PT. Remaja Rosdakarya
Yuniastuti, E. (2013). Peningkatan Keterampilan Proses, Motivasi, Dan Hasil Belajar Biologi Dengan Strategi Pembelajaran Inkuiri Terbimbing Pada Siswa Kelas VII SMP Kartika V1 Balikpapan. Jurnal Penelitian Pendidikan. $\quad$ 14(1), 78-86 